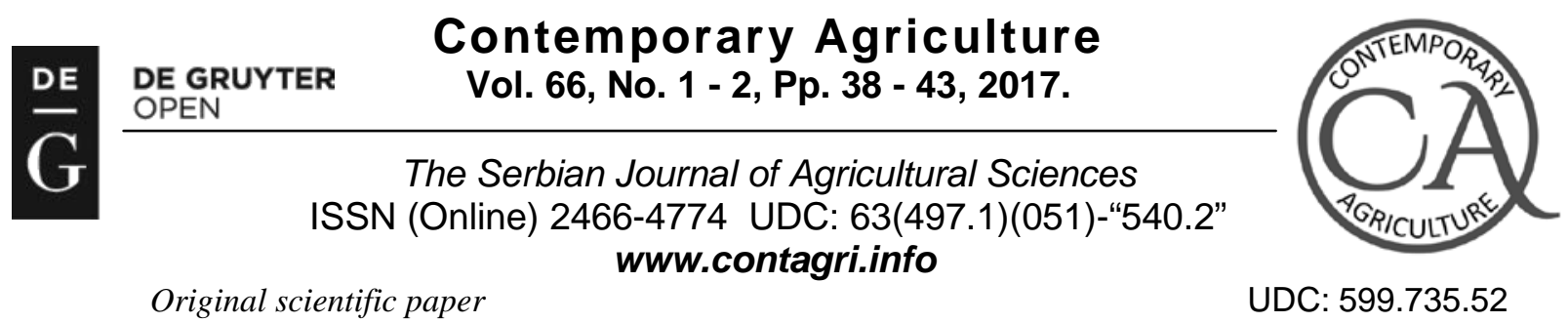

Original scientific paper

DOI: 10.1515/contagri-2017-0007

\title{
MORPHOMETRIC CHARACTERIZATION AND BODY MEASUREMENT CORRELATION IN DUBSKA PRAMENKA SHEEP
}

\author{
Božo VAŽIĆ ${ }^{1}$, Biljana ROGIĆl ${ }^{\star}$, Ivan PIHLER ${ }^{2}$, Milanka DRINIĆ ${ }^{1}$,Nebojša SAVIĆ ,
}

\begin{abstract}
Summary: The purpose of this study is to determine the morphometric characterization of Dubska Pramenka sheep and to establish a relationship between the most important body measurements of ewes and rams within the strain. The Dubska Pramenka is one of the biggest strains within the Pramenka breed. The wither heights of ewes and rams were $73.37 \mathrm{~cm}$ and 79.92 $\mathrm{cm}$ respectively, whereas the body lengths were $74.66 \mathrm{~cm}$ (ewes) and $80.42 \mathrm{~cm}$ (rams), and the rump heights were $73.72 \mathrm{~cm}$ (female) and $80.16 \mathrm{~cm}$ (male). Based on the data presented, it is evident that the Dubska Pramenka sheep has almost a square body shape with the rump height slightly greater than the wither height. The chest depth and shoulder width of ewes were 34.50 $\mathrm{cm}$ and $22.72 \mathrm{~cm}$ respectively, whereas those of males were $36.17 \mathrm{~cm}$ and $23.75 \mathrm{~cm}$. In both sheep genders, the hip width (ewes $21.92 \mathrm{~cm}$, rams $22.91 \mathrm{~cm}$ ) was lower than the shoulder width. The chest and shin perimeters of females were $98.72 \mathrm{~cm}$ and 9.31 $\mathrm{cm}$ respectively, whereas those of males were $103.25 \mathrm{~cm}$ and $10.91 \mathrm{~cm}$. The most significant correlation and statistical significance were recorded in relation to the measured wither and rump heights ( $r=0.856$ for females, $r=0.856$ for males) due to their constant increase during the growth and development of sheep. Conversely, the measurements of rump heights and chest perimeters did not indicate any correlation ( $r=-0.028$ for ewes, $r=0.004$ for rams).
\end{abstract}

Key words: sheep, Dubska Pramenka, morphometric measurements, correlation.

\section{INTRODUCTION}

The Dubska Pramenka originated in the village of Dub, the Travnik Municipality, Bosnia and Herzegovina. During the summer, the sheep live and graze on the mountain pastures of Vlašić. This is the reason why there are three names for this Pramenka strain in the old and new professional and scientific literature: Dubska, Travnička and Vlašićka. All three names refer to the same strain of sheep, which is characterized by specific morphometric and production characteristics. The Dubska Pramenka sheep inhabits the following municipalities in the vicinity of Vlašić: Teslić, Kotor Varoš, Kneževo, Travnik and Zenica. A wider area inhabited by this sheep strain extends from Serbia, through Bosnia and Herzegovina, to Croatia. The type of sheep production has been nomadic and it has remained in the narrow area of Dubska Pramenka breeding. In the former Yugoslavia, the sheep were moved from Vlašić to lowland areas (Vojvodina, Posavina and Slavonia) at the end of autumn and returned to Vlašić in late winter and early spring. The purpose of this type of sheep production was to reduce the investments in feed and accommodation, and to obtain maximum benefits. Displacements of people and animals occurred during the war in the former Yugoslavia. According to the estimates at the time of the war, around 10,000 sheep of the Dubska Pramenka strain went to Croatia (Pavic et al., 1999; Mioč et al., 2007). According to the wool quality, the Dubska Pramenka is classified as a sheep with rough fleece. On the basis of the purpose of production, it is classified as a three-purpose sheep: for milk, meat and wool. This sheep exerts excellent resistance and adaptability to existing living conditions, as well as the ability to walk long distances. In comparison with other Pramenka strains, it has marked morphometric characteristics and milk production. Consequently, this strain was used for the breeding of the Lička Pramenka strain (Šmalcelj, 1937). The knowledge about sheep morphometric characteristics is essential for proper breeding, and detailed characterization is important for strain genome preservation. The Dubska Pramenka belongs to the indigenous sheep of Bosnia and Herzegovina. Although this sheep strain is not at risk, it is necessary

\footnotetext{
${ }^{1}$ Božo Važić, PhD, Associated Profesor, Biljana Rogić, PhD, Teaching Assistant, Milanka Drinić, PhD, Associated Profesor, Nebojša Savić, PhD, Associated Profesor, University of Banja Luka, Faculty of Agriculture, Bulevar vojvode Petra Bojovića, 1A, 78000 Banja Luka, Republic of Srpska, Bosnia and Herzegovina.

${ }^{2}$ Ivan Pihler, PhD, Assistant Professor, University of Novi Sad, Faculty of Agriculture, Trg Dositeja Obradovića 8, 21000Novi Sad, Serbia.

•Corresponding author: BiljanaRogić, e-mail: biljana19@gmail.com, Tel.: 0038765286564
} 
to characterize it as part of animal genetic resources. The characterization of animal genetic resources covers all the activities associated with the identification of qualitative and quantitative characteristics as well as documentation of populations and breeds, including their habitats and pertaining production systems. The aim is to gain more knowledge about resources, their present and potential future use in food production (under defined environmental conditions) as well as their current status with regard to endangerment (FAO, 1984; Rege, 1992; Caput et al., 2010). According to Hrasnica and Ogrizek (1961), the Pramenka breed boasts a robust body constitution with a strong and well-proportioned body. The Dubska Pramenka sheep was crossbred with foreign fine-wooled types of sheep in the middle of the last century. Furthermore, the breed was also crossbred with some breeds developed for meat production. Providing adequate nutrition for these animals used to be a recurrent issue in the past. A number of factors have contributed to the morphometric characteristics of Dubska Pramenka sheep such as housing conditions, management, crossbreeding with other breeds, etc. Nowadays, there is a smaller number of sheep in the native area of the strain, whereas the housing conditions and management are much enhanced.

The purpose of this study is to determine the morphometric characterization of Dubska Pramenka sheep under new life circumstances, which persisted for a longer period of time. The goal is to determine the correlation between the recorded morphometric measurements.

\section{MATERIALS AND METHODS}

Data collection on the morphometric characteristics of Dubska Pramenka sheep was done in the spring (MayJune) on three farms located in Travnik (Babanovac and Donja Šišava) and Kotor Varoš (Dugo Selo). The sheep were bred in the traditional manner, i.e. during the spring, summer and autumn they were grazing, and in the winter they were nomadic. A total of 80 animals were measured: 68 ewes and 12 rams. All the animals have completed their growth and development (over 4 years old). The animals were taken randomly from the flock. The following eight most important morphometric traits were determined: wither height, rump height, body length, shoulder width, chest depth, hip width, chest perimeter and shin perimeter. The measurements of height, length and width were performed using Lydtin's stick, and the scope was taken by ribbons.

Data processing was performed using the method of descriptive statistics. Using the SPSS Statistics 17.0, the following values were calculated: the mean, standard deviation (SD), standard error of the mean (SE), coefficient of variation (CV) and minimum (Min) and maximum values (Max). In addition, the correlation coefficients were also calculated. The strength of correlation relationship was established according to the following scale: 0.0 to $0.10=$ no correlation; 0.10 to 0.25 = a very weak correlation; 0.25 to $0.40=$ a weak correlation; 0.40 to $0.50=$ a medium correlation; 0.50 to $0.75=$ a strong correlation; 0.75 to $0.90=$ a very strong correlation and 0.90 to $0.999=\mathrm{a}$ complete correlation (Tavčar, 1948, cit. Latinović 1996).

\section{RESULTS AND DISCUSSION}

The Pramenka sheep breed inhabits hilly and mountainous areas of the Balkan Peninsula characterized by pastures and meadows of various botanical composition. The Pramenka sheep which were raised on poor-quality pastures and poor-quality hay in the winter exhibited moderate morphometric characteristics compared to those raised on higher-quality nutrition. During the summer, the sheep lived and grazed on relatively good-quality pastures of Vlašić. In the winter, the sheep were moved from Vlašić to the lowland areas of the northern part of Bosnia and Herzegovina. Such living conditions have created a strong and resistant sheep with relatively good production characteristics. Table 1 shows the morphometric measurements of Dubska Pramenka sheep.

Table1.The morphometric measurements of Dubska Pramenka sheep, $\mathrm{cm}$

\begin{tabular}{|c|c|c|c|c|cc|}
\hline Morphometric measurements & Mean & SD & SE & CV & \multicolumn{2}{|c|}{ Min. Max. } \\
\hline Wither height & 73.37 & 3.85 & 0.47 & 5.25 & 65 & 86 \\
\hline Rump height & 73.72 & 4.02 & 0.47 & 5.45 & 67 & 85 \\
\hline Body length & 74.66 & 3.44 & 0.41 & 4.61 & 70 & 86 \\
\hline Shoulder width & 22.72 & 1.70 & 0.20 & 7.48 & 20 & 29 \\
\hline Chest depth & 34.50 & 1.71 & 0.20 & 4.95 & 31 & 39 \\
\hline Hip width & 21.95 & 1.06 & 0.13 & 4.83 & 20 & 25 \\
\hline Chest perimeter & 98.72 & 4.67 & 0.57 & 4.73 & 91 & 117 \\
\hline Shin perimeter & 9.31 & 0.60 & 0.07 & 6.44 & 8 & 11 \\
\hline
\end{tabular}


Dubska Pramenka sheep have greater rump heights than wither heights, and their bodies almost take the form of a square. In all primitive breeds encompassing Dubska Pramenka sheep, the depth is emphasized on the body while the width is moderate. The Pramenka sheep strain is capable of walking long distances and has a strong skeleton, which can be observed in the shin perimeter. Table 2 shows the correlation coefficients between the morphometric measurements of Dubska Pramenka sheep.

Table 2. The correlation coefficients between the morphometric measurements of Dubska Pramenka sheep.

\begin{tabular}{|c|c|c|c|c|c|c|c|c|}
\hline $\begin{array}{c}\text { Measurement } \\
\text { s }\end{array}$ & $\begin{array}{c}\text { Withe } \\
\text { rs } \\
\text { height }\end{array}$ & $\begin{array}{c}\text { Rump } \\
\text { height }\end{array}$ & $\begin{array}{c}\text { Body } \\
\text { length }\end{array}$ & $\begin{array}{c}\text { Shoulder } \\
\text { width }\end{array}$ & $\begin{array}{c}\text { Chest } \\
\text { depth }\end{array}$ & $\begin{array}{c}\text { Hip } \\
\text { width }\end{array}$ & $\begin{array}{c}\text { Chest } \\
\text { perimeter }\end{array}$ & $\begin{array}{c}\text { Shin } \\
\text { perimeter }\end{array}$ \\
\hline Wither height & 1 & $0.856^{\mathrm{b}}$ & $0.770^{\mathrm{b}}$ & 0.161 & $0.640^{\mathrm{b}}$ & 0.115 & 0.182 & $0.345^{\mathrm{b}}$ \\
\hline Rump height & - & 1 & $0.807^{\mathrm{b}}$ & 0.110 & $0.590^{\mathrm{b}}$ & 0.001 & -0.028 & $0.331^{\mathrm{b}}$ \\
\hline Body length & - & - & 1 & 0.178 & $0.568^{\mathrm{b}}$ & 0.046 & 0.022 & $0.538^{\mathrm{b}}$ \\
\hline $\begin{array}{c}\text { Shoulder } \\
\text { width }\end{array}$ & - & - & - & 1 & $0.258^{\mathrm{a}}$ & $0.484^{\mathrm{b}}$ & $0.490^{\mathrm{b}}$ & 0.086 \\
\hline Chest depth & - & - & - & - & 1 & 0.189 & $0.422^{\mathrm{b}}$ & $0.491^{\mathrm{b}}$ \\
\hline Hip width & - & - & - & - & - & 1 & $0.374^{\mathrm{b}}$ & 0.137 \\
\hline $\begin{array}{c}\text { Chest } \\
\text { perimeter }\end{array}$ & - & - & - & - & - & - & 1 & 0.136 \\
\hline Shin perimeter & - & - & - & - & - & - & & - \\
\hline
\end{tabular}

a level significant $0,05,{ }^{\mathrm{b}}$ level significant 0,01

The growth and development of Dubska Pramenka sheep is reflected in the correlations between the morphometric measurements of the strain. A very strong and statistically significant correlation was found between the wither height on one side and the rump height and body length on the other. The correlation between the wither height and chest depth is strong and highly statistically significant.

There is a very weak correlation between the wither height and shin perimeter, which is nevertheless highly statistically significant. There is a moderate correlation between the body length and the chest depth and shin perimeter, which is also highly statistically significant. The shoulder width is very weakly correlated with the chest depth and very strongly correlated with the hip width and shin perimeter. All of these correlations are highly statistically significant. The chest depth is moderately correlated with the chest perimeter and shin perimeter, whereas the hip width is weakly correlated with the chest perimeter. All of these correlations are also highly statistically significant.

Tabela 3.The morphometric measurements of Dubska Pramenka rams, cm

\begin{tabular}{|c|c|c|c|c|c|c|}
\hline Morphometric measurements & Mean & SD & SE & CV & Min. & Max. \\
\hline Wither height & 79.92 & 1.55 & 0.47 & 1.94 & 77 & 83 \\
\hline Rump height & 80.16 & 2.11 & 0.63 & 2.63 & 76 & 85 \\
\hline Body length & 80.42 & 5.15 & 1.55 & 6.40 & 72 & 87 \\
\hline Shoulder width & 23.75 & 1.88 & 0.56 & 7.91 & 21 & 27 \\
\hline Chest depth & 36.17 & 1.34 & 0.40 & 3.70 & 34 & 38 \\
\hline Hip width & 22.91 & 1.55 & 0.46 & 6.76 & 21 & 27 \\
\hline Chest perimeter & 103.25 & 5.18 & 1.56 & 5.02 & 93 & 110 \\
\hline Shin perimeter & 10.91 & 0.64 & 0.19 & 5.87 & 10 & 12 \\
\hline
\end{tabular}

In both sexes, the wither height values are lower than the rump height values. In males, the body length is greater than the wither height by $0.5 \mathrm{~cm}$, which is typical of square-shaped animals. The carcass of rams is characterized by emphasized depths and moderate widths. The rams of this strain are strong with a robust sceleton. 
Table 4. The correlation coefficients between the morphometric measurements of Dubska Pramenka rams.

\begin{tabular}{|c|c|c|c|c|c|c|c|c|}
\hline Measurements & $\begin{array}{c}\text { Wither } \\
\text { height }\end{array}$ & $\begin{array}{c}\text { Rump } \\
\text { height }\end{array}$ & $\begin{array}{c}\text { Body } \\
\text { length }\end{array}$ & $\begin{array}{c}\text { Shoulder } \\
\text { width }\end{array}$ & $\begin{array}{c}\text { Chest } \\
\text { depth }\end{array}$ & $\begin{array}{c}\text { Hip } \\
\text { width }\end{array}$ & $\begin{array}{c}\text { Chest } \\
\text { perimeter }\end{array}$ & $\begin{array}{c}\text { Shin } \\
\text { perimeter }\end{array}$ \\
\hline Wither height & 1 & $0.893^{\mathrm{b}}$ & -0.183 & 0.479 & 0.246 & 0.447 & 0.096 & $0.748^{\mathrm{b}}$ \\
\hline Rump height & - & 1 & 0.070 & 0.347 & 0.342 & 0.207 & 0.004 & $0.687^{\mathrm{a}}$ \\
\hline Body length & - & - & 1 & 0.347 & 0.342 & 0.207 & 0.004 & $0.687^{\mathrm{a}}$ \\
\hline Shoulder width & - & - & - & 1 & 0.314 & $0.679^{\mathrm{b}}$ & $0.589^{\mathrm{a}}$ & $0.746^{\mathrm{b}}$ \\
\hline Chest depth & - & - & - & - & 1 & 0.166 & $0.700^{\mathrm{b}}$ & 0.501 \\
\hline Hip width & - & - & - & - & - & 1 & $0.603^{\mathrm{a}}$ & $0.664^{\mathrm{a}}$ \\
\hline Chest perimeter & - & - & - & - & - & - & 1 & 0.484 \\
\hline Shin perimeter & - & - & - & - & - & - & & $2^{2}$ \\
\hline
\end{tabular}

${ }^{\mathrm{a}}$ level significant $0.05,{ }^{\mathrm{b}}$ level significant 0.01

The correlations between several morphometric measurements were determined for both sexes. There is a strong correlation between the wither height and rump height in both sexes, which is highly statistically significant. The wither height and shin perimeter of rams are strongly correlated with a high statistical significance. In females, the correlation between the wither height and shin perimeter is poor, but highly statistically significant. Sheep with greater wither heights have higher rump heights and front leg shin perimeters. The statistically significant correlation between the rump height and shin perimeter was found in both sexes. This correlation was poor in females and strong in males. The correlation between the body length and shin perimeter is highly significant and strong in both sexes.

In comparison with the wither height, rump height and body length, the shin perimeter was highly statistically significant and the correlation ranged from weak to strong. The correlation between the shoulder width and hip width and chest perimeter was strong and highly statistically significant. Ewes and rams with a broad chest have a wider pelvis and chest perimeter. The correlation between these values was highly statistically significant. The correlation between the hip width and chest perimeter ranged from weak to strong in both sexes, which was highly statistically significant.

Provided these measurements are compared with the measurements in previous studies, we can conclude that there has been some changes in the morphometric characteristics of Dubska Pramenka sheep in the area of its origin. According to the research of Frajlih (cit. Mitic, 1984), the wither heights of ewes and rams were $66.87 \mathrm{~cm}$ and 72.90 $\mathrm{cm}$ respectively. Pavic et al. (1999) stated in their research that the sheep had the following measurements: the wither height $66.76 \mathrm{~cm}$, body length $73.86 \mathrm{~cm}$ and chest width $22.15 \mathrm{~cm}$. The values for the rams were as follows: the wither height $72.64 \mathrm{~cm}$, body length $80.79 \mathrm{~cm}$ and chest width $21.71 \mathrm{~cm}$. The same authors concluded that the exterior of Dubska Pramenka sheep stayed the same, i.e. it had not changed in the period of 60 years prior to their research.

Those authors conducted their research on the plateau Vrhovina, the Republic of Croatia, where the climatic and nutritive conditions are significantly different in relation to the indigenous areas of the strain. Antunovic et al. (2013) investigated the exterior measurements of Dubska Pramenka sheep in western Slavonia. These sheep were kept in a semi-intensive manner, which drastically differs from the nomadic manner of sheep keeping in the native area of Dubska Pramenka sheep. Those authors recorded the following measurements for the females: the wither height $69.80 \mathrm{~cm}$, body length $85.70 \mathrm{~cm}$ and chest width $27.40 \mathrm{~cm}$. The measurements for the males were as follows: 75.50 $\mathrm{cm}, 86.60 \mathrm{~cm}$ and $26.60 \mathrm{~cm}$. Based on the results of these and other authors, it can be concluded that the morphometric measurements of Dubska Pramenka sheep have changed in a positive manner in the indigenous areas of the strain. The main reason for this is a smaller number of sheep raised on large pasture areas and improved nutritive conditions. The Dubska Pramenka belongs to a group of indigenous sheep with distinguishing characteristics. According to Ivankovic et al. (2009), males and females of the Kupreška Pramenka strain have inferior morphometric characteristics in relation to Dubska Pramenka sheep (ewe wither height $65.30 \mathrm{~cm}$ and ram wither height $70.88 \mathrm{~cm}$ ). The Dupska Pramenka is much more developed than the following indigenous sheep from 
Croatia: Lička Pramenka, Krcka, Rapska and Paska sheep (Mioč et al., 1998; Mioč et al., 2004; Pavic et al., 2005; and Mioč et al., 2006). Only the Istrian sheep had emphasized morphometric measurements compared to the Dupska Pramenka sheep (Mikulec et al., 2007).

\section{CONCLUSION}

On the basis of this research, it can be concluded that the morphometric measurements of Dupska Pramenka sheep have changed in a positive manner in relation to the sheep occupying the same habitat sixty years ago. Nowadays, the sheep of both sexes are larger, longer and wider with stronger skeletons. The explanation for this lies within the enhanced conditions of sheep breeding. There is a smaller number of sheep on large pasture areas compared to the previous period. Therefore, the sheep can be better kept and fed in all seasons. In addition, the nomadic manner of sheep keeping is slowly becoming obsolete and facilities for better housing during the winter are being built. Furthermore, the sheep receive more feed, including corn and concentrate. All the abovementioned considerations have had an impact on improving the morphometric characteristics of Dubska Pramenka sheep. The correlation coefficients between the morphometric measurements of Dubska Pramenka sheep express the relationship between the individual parts of the body. The sheep with greater wither heights also have greater rump heights, longer bodies, deeper chests and greater shin perimeters. The sheep with broad chests have greater chest depths, hip widths and chest perimeters. Moreover, the sheep with greater chest depths have higher chest perimeters, whereas the sheep with greater hip widths have larger chest perimeters.

\section{REFERENCES}

ANTUNOVIĆ, Z., VRBAS, D., ŠPERANDAM., NOVOSELEC, J., KIR Ž., GALOVIĆ D.: Fenotipske odlike travničke pramenke u zapadnoj Slavoniji. Zbornik radova, 48. hrvatski i 8. međunarodni simpozij agronoma Dubrovnik, 703 - 706, 2013 ;

CAPUT, P., IVANKOVIĆ, A., MIOČ, B.: Očuvanje biološke raznolikosti u stočarstvu. Hrvatska mljekarska udruga, Zagreb, pp. 59-62, 2010;

fao: Animal Genetic Resources Conservation by Management, Data Banks and Training. FAO Anim. Prod. Health, Paper 44/1, 1984;

HRASNICA, F., OGRIZEK, A.: Stočarstvo - opći dio, Zagreb, pp. 251-252, 1961;

IVANKOVIĆ, S., ČUKOVIĆ, M., BATINIĆ, V., MIOČ, B., IVANKOVIĆ, A.,: Eksterijerne odlike kupreške pramenke. Stočarstvo, 63(3)163 - 173, 2009;

LATINOVIĆ, D.: Populaciona genetika i oplemenivanje domaćih životinja. Praktikum. Univerzitet u Beogradu, pp. 48, 1996;

MIKULEC, D., PAVIĆ, V., SUŠIĆ, V., MIOČ, B., MIKULEC, K., BARAĆ, Z., PRPIĆ, Z., VNUČEC, I.: Odlika vanjštine različitih kategorija istarskih ovaca. Stočarstvo, 61(1)13 - 22,2007;

MIOČ, B., PAVIĆ, V., BARAĆ, Z.: Odlike eksterijera ličke pramenke. Stočarstvo, 52(2)93 - 98, 1998;

MIOČ, B., PAVIĆ, V., IVANKOVIĆ, A., BARAĆ, Z., VNUČEC, I., ČOKLJAT, Z.: Odlike eksterijera i polimorfizma proteina krvi krčke ovce. Stočarstvo, 58(5)331 - 342, 2004;

MIOČ, B., PAVIĆ, V., BARAĆ, Z., SUŠIĆ, V., PRPIĆ, Z., VNUČEC, I., MULC, D.: Vanjština rapske ovce. Stočarstvo, 60(3)163 - 171, 2006;

MIOČ, B., PAVIĆ, V., SUŠIĆ, V.: Ovčarstvo. Hrvatska mljekarska udruga, pp. 87-88, Zagreb, 2007.

MITIĆ, N.: Ovčarstvo. Zavod udžbenika za nastavna sredstsva, Beograd, pp. 154, 1984.

PAVIĆ, V., MIOČ, B., BARAĆ, Z.: Odlike eksterijera travničke pramenke. Stočarstvo, 53(2) 83 - 89, 1999;

PAVIĆ, V., MIOČ, B., BARAĆ, Z., VNUČEC, I., SUŠIĆ, V., ANTUNAC, N., SAMARŽIJA D.: Vanjština paške ovce. Stočarstvo, 59(2)83 - 90, 2005;

REGE, J. E. O.: Background to ILCA's animal genetic resources characterization project, objectives and agenda for the research planning workshop. In: Animal genetic resources: their characterization, conservation and utilization.(ed. Rege, J. E. O., Lipner, M. E.): Research planning workshop, ILCA, 19 - 21. 02. 1992., Addis Ababa, Ethiopia, pp. 55-59;

SPSS STATISTICS 17.0, Release 17.0.0. This product uses WinWrap Basic, Copryght 1993-2007 Polar Engineering and Consulting, http:/www.winwrap.com/, Aug 23, 2008;

ŠMALCELJ, I.: Beitrag zur Kenntnis der bosnischen Zackelschafe. Z.f. Tierzucht und Züchtgsbiol, 29:3, Berlin, 1937. 


\title{
MORFOMETRIJSKA KARAKTERIZACIJA I KORELATIVNI ODNOSI IZMEĐU MJERA NA TIJELU OVACA DUBSKE PRAMENKE
}

\author{
Božo VAŽIĆ, Biljana ROGIĆ, Milanka DRINIĆ, Nebojša SAVIĆ, Ivan PIHLER
}

Izvod: Cilj ovog rada je bio da se utvrdi morfometrijska karakterizacija dupske pramenke i da se utvrde korelativni odnosi između najvažnijih mjera na tijelu ovaca i ovnova navedenog soja. Dubska pramenka spada među najkrupnije sojeve pramenke čija visina grebena za ovce iznosi $73,37 \mathrm{~cm}$, a ovnova 79,92 cm; dužina trupa kod ovaca je 74,66 cm, kod ovnova 80,42 cm; visina krsta kod ovaca je 73,72, a ovnova 80,16. Na osnovu iznesenih podataka vidi se da ovce dupske pramenke imaju skoro kvadratan oblik tijela, čija visina krsta je nešto veća od visine grebena. Grudi su kod ovaca duboke $34,50 \mathrm{~cm}$ sa širinom od 22,72 cm, kod ovnova dubina grudi je $36,17 \mathrm{~cm}$ a širina je 23,75 cm. Kod oba pol, širina kukova (ovce 21,95 cm, ovnovi 22,91 cm) je bila manja od širine grudi. Obim grudi kod ovaca je bio $98,72 \mathrm{~cm}$ a obim cjevanice $9,31 \mathrm{~cm}$, a kod ovnova 103,25 cm i 10,91 cm. Kod ovaca i ovnova najveću korelaciju i statistički visoko značajnu pokazale su mjere koje se u procesu rasta i razvoja uzajamno razvijaju, a to su: visina grebena i visina krsta ( $r=0,856$ za ovce i $r=0,856$ za ovnove). $S$ druge strane, visina krsta $\mathrm{i}$ obim grudi nisu pokazale korelativni odnos ( $r=-0,028$ za ovce i $r=0,004$ za ovnove).

Ključne reči: ovca, dubska pramenka, morfometrijske mjere, korelacije

Received / Primljen: 03.11.2016. Accepted / Prihvaćen: 04.07.2017. 